\title{
Exacerbation of Damage and Altered NF- $\kappa$ B Activation in Mice Lacking Tumor Necrosis Factor Receptors after Traumatic Brain Injury
}

\author{
Patrick G. Sullivan, ${ }^{1,2}$ Annadora J. Bruce-Keller, ${ }^{1}$ Alexander G. Rabchevsky, ${ }^{1}$ Sylivia Christakos, ${ }^{4}$ \\ Daret K. St. Clair, ${ }^{3}$ Mark P. Mattson, ${ }^{1,2}$ and Stephen W. Scheff 1,2 \\ 1Sanders-Brown Center on Aging, ${ }^{2}$ Department of Anatomy and Neurobiology, and ${ }^{3}$ Graduate Center for Toxicology, \\ University of Kentucky, Lexington, Kentucky 40536-0230, and 4Department of Biochemistry and Molecular Biology, \\ University of Medicine and Dentistry of New Jersey Medical School, Newark, New Jersey 07103
}

Tumor necrosis factor $\alpha$ (TNF $\alpha)$ is widely expressed in both neurons and glia and has been shown to be upregulated after traumatic brain injury (TBI). TNF $\alpha$ receptor activation results in activation of the transcription factor nuclear factor $\kappa \mathrm{B}(\mathrm{NF}-\kappa \mathrm{B})$, which may serve an antiapoptotic role via the induction of target genes manganese superoxide dismutase (MnSOD) and/or calbindin. In the present study, we used a controlled cortical impact model of TBI with pertinent lines of transgenic mice to combine both morphological characterization and molecular analysis to elucidate the role of TNF $\alpha$ after TBI. Measurements of both the lesion volume and the blood-brain barrier breach indicated exacerbations in mice rendered genetically deficient in both the p55 and p75 TNF $\alpha$ receptors (TNFR-KO) compared with wild-type animals. Additionally, animals genetically altered to overexpress MnSOD showed a significant decrease in lesion volume compared with that of control littermates, whereas no alterations were observed in mice lacking the calcium-binding protein calbindin D28k. Analysis of NF- $\kappa \mathrm{B}$ activation and relative levels of MnSOD revealed delayed responses in the injured cortex of TNFR-KO animals compared with wild-type animals, implying that endogenous $\mathrm{TNF} \alpha$ may be neuroprotective after TBI.

Key words: neurotrauma; blood-brain barrier; transgenic; cortical impact; oxidative stress; TNF $\alpha$
Neuronal degeneration after traumatic brain injury (TBI) is believed to evolve in a biphasic manner consisting of the primary mechanical insult followed by a progressive secondary necrosis (Mattson and Scheff, 1994; Siesjo et al., 1995). Characteristic responses to trauma or excitotoxic insults to the CNS include the extravasation of serum proteins through the damaged bloodbrain barrier (BBB) (Povlishock and Kontos, 1992; Dietrich et al., 1994; Baldwin et al., 1996), activation of resident neuroglial cells (Coffey et al., 1990; Andersson et al., 1991; Soares et al., 1995; Jensen et al., 1997), and a rapid increase in the production of proinflammatory cytokines (Goodman et al., 1990; Taupin et al., 1993; Liu et al., 1994; Fan et al., 1996; Feuerstein et al., 1997), most notably tumor necrosis factor $\alpha(\mathrm{TNF} \alpha)$.

$\mathrm{TNF} \alpha$ is a $17 \mathrm{kDa}$ pleiotropic peptide that forms multimers that actively bind TNF receptors (TNFR) expressed on both glia and neurons (Merrill, 1991; Wolvers et al., 1993). Two different TNFR (p55 and p75) have been identified (Beutler and Van Huffel, 1994a,b) and shown to mediate differential cellular responses using distinct pathways (Kinouchi et al., 1991; Tartaglia et al., 1991). For instance, the signal transduction pathway used by the p55 TNFR results in the activation of the transcription factor nuclear factor $\kappa \mathrm{B}(\mathrm{NF}-\kappa \mathrm{B})$ (Kolesnick and Golde, 1994; Goodman and Mattson, 1996; Mattson et al., 1997a,b). Signals that

Received Nov. 6, 1998; revised April 26, 1999; accepted May 11, 1999.

This work was supported by the National Institutes of Health United States Public Health Service Grants NS31220 to S.W.S., CA59835 to D.K.S.C., and NS29001, NS35253, and AG608119 to M.P.M. We thank Tonya Gibson and Dr. Judith Nemith for technical assistance.

Correspondence should be addressed to Dr. Stephen Scheff, 229 Sanders-Brown Center on Aging, University of Kentucky, Lexington, KY 40536-0230.

Copyright (C) 1999 Society for Neuroscience $0270-6474 / 99 / 196248-09 \$ 05.00 / 0$ activate NF- $\kappa$ B cause the dissociation of $\mathrm{I}-\kappa \mathrm{B}$ and the subsequent release of the p50-p65 dimer that translocates to the nucleus where it binds to specific $\kappa \mathrm{B}$ DNA consensus sequences located in the enhancer region of target genes, including manganese superoxide dismutase (MnSOD) and calbindin (Das et al., 1995; Mattson et al., 1995; Wong, 1995).

$\mathrm{TNF} \alpha$ has long been postulated to contribute to the neuropathology observed after TBI because of its upregulation during inflammatory responses, and strategies to inhibit the actions of TNF $\alpha$ have been developed (for review, see Morganti-Kossmann et al., 1992). However, on the basis of emerging evidence that TNF $\alpha$ may be neuroprotective after CNS insults (Cheng et al., 1994; Barger et al., 1995; Bruce et al., 1996; Mattson et al., 1997; Liu et al., 1998), we sought to characterize further the role of TNF $\alpha$ after head trauma using a unilateral controlled cortical impact model with pertinent strains of transgenic mice to assess histological and molecular changes after TBI. The lesion volumes resulting from TBI were compared among TNFR-knock-out mice (TNFR-KO), wild type, and calbindin D28k-knock-out mice (CaBP-KO). Previous studies have demonstrated the neuroprotective properties of calbindin (Scharfman and Schwartzkroin, 1989; Mattson et al., 1991; Cheng et al., 1994) and have reported upregulation of calbindin by TNF $\alpha$ (Cheng et al., 1994). Calbindin has also been reported to be upregulated after TBI (Lowenstein et al., 1994; Mattson et al., 1995). In the present experiments we also compared the extent of BBB breakdown in the ipsilateral hemispheres by measuring the extravasation of endogenous $\mathrm{IgG}$, as well as exogenously applied horseradish peroxidase (HRP). To investigate the possible involvement of MnSOD, we compared cortical damage in MnSOD-overexpressing mice with that in wild-type littermates after TBI. Additionally, 
MnSOD immunoreactivity was measured in situ in the ipsilateral and contralateral cortex of both TNFR-KO and wild-type mice. Lastly, to address the putative mechanisms involved, we evaluated activation of $\mathrm{NF}-\kappa \mathrm{B}$ over time after injury.

\section{MATERIALS AND METHODS}

Animals. A total of 119 mice were used in the present study, and all were housed in group cages ( 4 per group) on a $12 \mathrm{hr}$ light/dark cycle with food and water available ad libitum. All animal procedures were approved by the institutional animal care and use committee. The gene-targeting strategy used to generate lines of mice lacking either the p55 TNF receptor $(\mathrm{p} 55-/-)$ or the $\mathrm{p} 75$ receptor $(\mathrm{p} 75-/-)$ has been described previously (Zheng et al., 1995). Mice lacking both p55 and p75 (TNFR$\mathrm{KO})$ were generated by the cross-breeding of $\mathrm{p} 55-/-$ mice with $\mathrm{p} 75-/-$ mice. Wild-type mice were $\mathrm{C} 57 \mathrm{BL} / 6 \times 129\left(\mathrm{~F}_{1}\right)$; all knock-out lines were maintained on a random C57BL/6 $\times 129$ background. Mice lacking either p55 or both TNF receptors show no overt phenotypes and reproduce normally but do exhibit altered responses of lymphocytes to a variety of infectious agents (Pfeffer et al., 1993; Zheng et al., 1995). Previous analyses revealed no overt alterations in brain structure or in performance on behavioral tests in $\mathrm{p} 55 / \mathrm{p} 75-/-$ mice compared with their wild-type counterparts (Bruce et al., 1996). The generation of the CaBP-KO mice was accomplished by a targeting approach described previously in detail (Airaksinen et al., 1997). Experiments were performed in homozygous $\mathrm{CaBP}-\mathrm{KO}$ mice and wild-type background strain $(\mathrm{C} 57 \mathrm{BL} / 6 \times 129)$ control mice. The CaBP-KO mice exhibit no overt phenotype but do show deficits in motor coordination and alterations in calcium regulation in cerebellar Purkinje cells (Airaksinen et al., 1997). We observed no differences in hippocampal structure or in the numbers of neurons per section in any of the subpopulations of hippocampal neurons. The generation and characterization of transgenic mice expressing human MnSOD under the control of the human $\beta$-actin promoter were described previously (Yen et al., 1996). These mice overexpress MnSOD (MnSODtg) in the brain at a level two- to threefold greater than that of wild-type mice and have been shown to exhibit decreased brain damage after focal cerebral ischemia (Keller et al., 1998).

Experimental groups and surgical procedures. Four separate paradigms were used in this study. The first set of experiments examined the lesion volume and the BBB breach to IgG after TBI using adult female mice $(20-25 \mathrm{gm})$ from one of three different groups. Group 1 mice $(n=15)$ were lacking both the $\mathrm{p} 55$ and $\mathrm{p} 75 \mathrm{TNF}$ receptors (TNFR-KO), group 2 mice $(n=12)$ were lacking calbindin D28k (CaBP-KO), and group 3 was wild-type C57BL/ $6 \times 129$ mice $(n=15)$. In addition, four TNFR-KO and four wild-type mice were used to assess BBB breakdown to exogenous HRP. In the second set of experiments, MnSODtg $(n=8)$ and control littermates $(n=9)$ received $1 \mathrm{~mm}$ unilateral cortical impacts using the same procedures described for lesion volume comparisons (see below). The third set of experiments examined the relative levels of MnSOD immunoreactivity in situ in TNFR-KO $(n=7)$ versus wild-type $(n=7)$ mice after a $1 \mathrm{~mm}$ cortical impact or sham surgery $(n=2 /$ group $)$ at $9 \mathrm{hr}$ after injury. Finally, additional wild-type $(n=18)$ and TNFR-KO $(n=18)$ mice were subjected to a $1 \mathrm{~mm}$ cortical impact to assay NF- $\kappa \mathrm{B}$ activation over time after injury.

All subjects were anesthetized with Avertin $(0.175 \mathrm{mg} / \mathrm{kg})$ and placed in a stereotaxic frame (Kopf, Tujunga, CA) before TBI. The head was positioned in the horizontal plane with the nose bar set at negative 5. By the use of sterile procedures, the skin was retracted, and a $3 \mathrm{~mm}$ craniotomy was made lateral to the sagittal suture and centered between bregma and lambda. The skull cap was carefully removed without disruption of the underlying dura. The exposed cortex was injured using a pneumatically controlled impactor device as described previously (Baldwin et al., 1996, 1997; Scheff et al., 1997). Briefly, the impactor rod tip with a $2 \mathrm{~mm}$ diameter compressed the cortex at $3.5 \mathrm{~m} / \mathrm{sec}$ to a depth of $1 \mathrm{~mm}$. After injury, Surgiseal (Johnson and Johnson, Arlington, TX) was laid on the dura, and the skull cap was replaced. The skin was then sutured together, and the animals were placed on a heating pad to recover. Sham animals underwent the same procedures except for the cortical impact. Three TNFR-KO, two wild-type, and five CaBP-KO animals died within $48 \mathrm{hr}$ after injury.

Lesion volumes. Seven days after injury, the animals were anesthetized with Nembutal and transcardially perfused with $30 \mathrm{ml}$ of PBS followed by $60 \mathrm{ml}$ of a $4 \%$ paraformaldehyde in PBS. The brains were removed, post-fixed for $12 \mathrm{hr}$, and then cryoprotected in $15 \%$ sucrose in PBS. The frozen brains were then sectioned at $40 \mu \mathrm{m}$ in the coronal plane with a freezing microtome, and every fifth section was mounted onto vectabonded slides and stained with cresyl violet. Individual sections throughout the rostrocaudal extent of the lesion, extending from the septal area to the most posterior hippocampus [interaural levels 8.2-2.2 (Paxinos and Watson, 1982)], were viewed at high magnification, and the area that contained necrotic or damaged tissue was carefully circumscribed with computerized image analysis consisting of a Macintosh Quadra 950 computer using an Hitachi CCD camera mounted on an Olympus BH2 microscope and NIH Image version 1.61. The area of the entire ipsilateral cortex was also measured for each section so that the volume of the damaged cortex and the volume of the entire cortical region could be determined using the Cavalieri method (Michel and Cruz-Orive, 1988). The amount of cortical damage is expressed as a percentage of the total cortical volume. This alleviates any need to adjust numbers because of possible differential shrinkage resulting from fixation and tissue processing. All slides were ranked blindly with respect to genotype.

Immunohistochemistry. The extravasation of endogenous $\mathrm{IgG}$ was used to examine the extent of BBB disruption after TBI. Every fifth section $(40 \mu \mathrm{m})$ from each animal (i.e., wild type, TNFR-KO, and CaBP-KO) was stained with biotinylated anti-mouse $\operatorname{IgG}(5 \mu \mathrm{g} / \mathrm{ml}$; Vector Laboratories, Burlingame, $\mathrm{CA}$ ), and the $\mathrm{ABC}$ method was used using diaminobenzidine as the chromogen. Before addition of antibodies, free-floating sections were incubated in $3 \% \mathrm{H}_{2} \mathrm{O}_{2}$ in PBS to quench endogenous peroxidase activity and then blocked with $1.5 \%$ normal horse serum. All samples were run simultaneously in 12 -well plates using Costar screen systems to ensure equal incubation times for all staining procedures. Control sections from each animal had either the primary antibody omitted or were incubated with the avidin-biotin complex alone. All slides were ranked blindly with respect to genotype.

Measurements of $B B B$ disruption. Differences in immunostaining for IgG extravasation among groups were quantified using NIH Image version 1.61. The system was calibrated against a Kodak Optical Density Standard (Eastman Kodak, Rochester, NY), and a standard curve was generated. The region of IgG immunoreactivity in the hemisphere ipsilateral to the injury site for each coronal section was outlined, and the average mean densitometric level for each animal was obtained. The densitometric readings, minus background levels obtained from the equivalent area in the contralateral hemisphere were summed, and the group means were analyzed by a one-way ANOVA followed by Scheffe post hoc analysis. Additionally, the extent of the BBB breach was assessed by first setting a threshold based on the densitometric readings in the contralateral hemisphere and then measuring the area of the ipsilateral hemisphere that was above this threshold. The areas were then summed to obtain a volume for each animal. To extend our BBB findings further, 12 and $24 \mathrm{hr}$ after TBI, we injected additional wild-type $(n=4)$ and TNFR-KO $(n=4)$ mice intravenously with $15 \mathrm{mg}$ of HRP (type VI-A; Sigma, St. Louis, MO) in $250 \mu \mathrm{l}$ of saline $30 \mathrm{~min}$ before perfusion with $1 \%$ paraformaldehyde and $1.25 \%$ glutaraldehyde in PBS containing $10 \%$ sucrose. The protocol of Mesulam (1978), using 3,3',5,5'-tetramethylbenzidine as the chromogen, was used to reveal the extravasation of exogenous HRP in the brain. All slides were ranked blindly with respect to genotype.

In situ MnSOD immunofluorescence. Relative levels of MnSOD protein in wild-type $(n=7)$ and TNFR-KO $(n=7)$ injured mice $(1 \mathrm{~mm}$ cortical contusion) and sham-operated mice ( $n=2$ /group) were determined by methods similar to those described previously (Bruce et al., 1996). Fresh-frozen coronal brain sections ( $14 \mu \mathrm{m}$ cryostat sections) were thawmounted on slides and immediately fixed for $30 \mathrm{~min}$ at $4^{\circ} \mathrm{C}$ in Zamboni's fixative ( $2 \%$ paraformaldehyde and $0.15 \%$ picric acid in PBS). Tissue sections were incubated for $30 \mathrm{~min}$ in a solution of $0.2 \%$ Triton $\mathrm{X}-100$ in PBS and then for $1 \mathrm{hr}$ in the presence of blocking serum. Sections were incubated overnight at $4^{\circ} \mathrm{C}$ in the presence of sheep polyclonal antibody to MnSOD (1:500; Biodesign), followed by sequential incubations in biotinylated anti-sheep $\mathrm{IgG}$ and Oregon green-conjugated streptavidin (Molecular Probes, Eugene, OR). Fluorescence images (excitation, 420$490 \mathrm{~nm}$ ) were acquired and quantified from both the ipsilateral and contralateral cortex using an Optronics VI-470 CCD video camera (Optronics Engineering, Goleta, CA) mounted on a Leitz microscope (Wetzlar, Germany) and Bioquant Image Analysis System version 3.15s (R \& M Biometrics, Nashville, TN) calibrated according to manufacturers' specifications. Sections (six per animal) equally spaced throughout the rostrocaudal extent of the lesion were sampled blindly with respect to genotype using a $200 \mu \mathrm{m} \times 200 \mu \mathrm{m}$ image frame (40× magnification) placed both medial and lateral to the lesion on the ipsilateral hemisphere and the corresponding regions of the contralateral hemisphere. Sections from sham-operated animals were mounted onto each slide to obtain and 

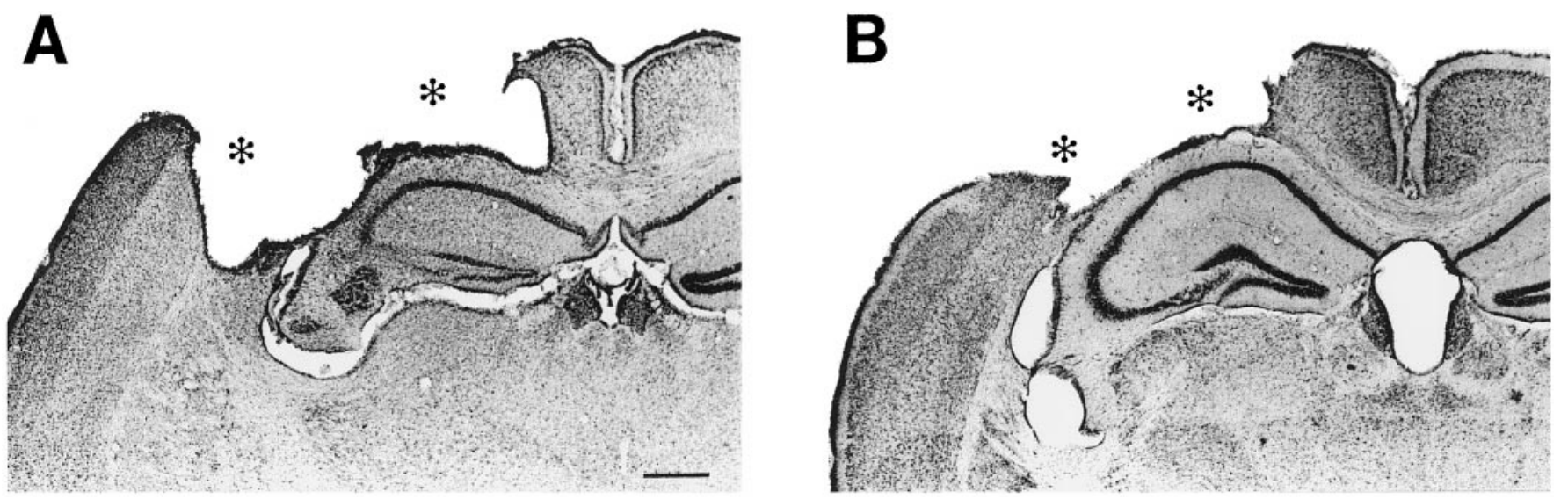

Figure 1. Coronal sections through the damaged cerebral hemispheres of adult mice stained with cresyl violet $7 \mathrm{~d}$ after a moderate $(1 \mathrm{~mm})$ cortical impact. The injury results in an obvious cavitation in the cortex immediately below the impact site, as indicated by asterisks. TNFR-KO animals $(A)$ demonstrated significantly larger lesion volumes compared with those in wild-type animals $(B)$. Scale bar, $500 \mu \mathrm{m}$.

subtract background measurements. The mean optical densities were then calculated for the ipsilateral and contralateral hemisphere of each animal. The optical densities were then expressed as a percentage of the contralateral hemisphere.

Electrophoretic mobility gel-shift assay for $N F-\kappa B$ activation. Wild-type and TNFR-KO animals were killed at 3,12 , or $24 \mathrm{hr}$ after TBI. The injured and contralateral hemispheres (less cerebellum) from two animals per group were pooled, and each hemisphere was dissected into different regions (i.e., hippocampus and cortical area, including penumbra). The ipsilateral regions were compared with the corresponding regions in the uninjured hemisphere. After dissection, nuclear extracts were prepared as described previously (Andrews and Faller, 1991). Briefly, the tissue was homogenized using a handheld tissue homogenizer in a lysis buffer (10 mM HEPES-KOH, pH 7.9, $1.5 \mathrm{~mm} \mathrm{MgCl}_{2}, 10$ $\mathrm{mm} \mathrm{KCl}, 0.5 \mathrm{~mm}$ dithiothreitol, $1 \% \mathrm{NP}-40,0.2 \mathrm{~mm}$ phenylmethylsulfonyl fluoride, $5 \mu \mathrm{g} / \mathrm{ml}$ aprotinin, $4 \mu \mathrm{g} / \mathrm{ml}$ pepstatin, $4 \mu \mathrm{g} / \mathrm{ml}$ leupeptin, and 20 $\mu \mathrm{g} / \mathrm{ml}$ trypsin inhibitor) and centrifuged at $4000 \times g\left(4^{\circ} \mathrm{C}\right)$ for $5 \mathrm{~min}$. The supernatant was discarded, and the pellet was resuspended in extraction buffer (20 mM HEPES-KOH, pH 7.9, 25\% glycerol, $420 \mathrm{~mm} \mathrm{NaCl}, 1.5$ $\mathrm{mm} \mathrm{MgCl}_{2}, 0.2 \mathrm{~mm}$ EDTA, $0.5 \mathrm{~mm}$ dithiothreitol, $0.2 \mathrm{~mm}$ phenylmethylsulfonyl fluoride, $5 \mu \mathrm{g} / \mathrm{ml}$ aprotinin, $4 \mu \mathrm{g} / \mathrm{ml}$ pepstatin, $4 \mu \mathrm{g} / \mathrm{ml}$ leupeptin, and $20 \mu \mathrm{g} / \mathrm{ml}$ trypsin inhibitor), vortexed, and placed on ice for $30 \mathrm{~min}$ before centrifugation at $12,000 \times g\left(4^{\circ} \mathrm{C}\right)$ for $20 \mathrm{~min}$. The supernatants, containing DNA-binding proteins, were then used for gel-shift assays using methods similar to those described previously (Barger et al., 1995; Mattson et al., 1997b) and using a commercially available assay kit (Promega, Madison, WI). Briefly, 100,000 cpm of ${ }^{32} \mathrm{P}$-labeled double-stranded DNA (consensus $\kappa \mathrm{B}$-binding sequence) was added to a reaction mixture containing $5 \mu \mathrm{l}$ of nuclease-free water, $2 \mu \mathrm{l}$ of gel-shift-binding buffer ( $5 \mathrm{mM} \mathrm{MgCl}_{2}, 20 \%$ glycerol, $2.5 \mathrm{~mm}$ EDTA, $2.5 \mathrm{~mm}$ dithiothreitol, $250 \mathrm{~mm} \mathrm{NaCl}, 0.25 \mathrm{mg} / \mathrm{ml}$ poly(dl-dC)-poly(dl$\mathrm{dC}$ ), and $50 \mathrm{~mm}$ Tris-HCl, $\mathrm{pH} 7.5$ ), and $2 \mu \mathrm{l}$ of nuclear extract. The reaction remained at room temperature for $20 \mathrm{~min}$ and was stopped by adding $1 \mu \mathrm{l}$ of $10 \times$ gel-loading buffer ( $40 \%$ glycerol, $0.2 \%$ bromphenol blue, and $250 \mathrm{~mm}$ Tris-HCl, $\mathrm{pH}$ 7.5). Control reactions included the substitution of nonspecific radiolabeled DNA in place of the radiolabeled $\kappa \mathrm{B}$ DNA and the addition of unlabeled competitor DNA to the reaction mixture. Nuclear extract from activated HeLa cells was used as a positive control for activated NF- $\kappa$ B. Samples were separated via a $4 \%$ nondenaturing acrylamide gel by electrophoresis. The gel was then dried, exposed to a phosphorous screen, and imaged with a Fuji FLA 2000 (Fuji Medical Systems, Stamford, CT). Only one band was shifted, representing the bound consensus $\kappa \mathrm{B}$-binding sequence, and was quantified using MACBAS 2.5 software. To ensure linear measurements, we ran known standards in parallel.

\section{RESULTS}

\section{Exacerbation of cortical damage in TNFR-KO but not CaBP-KO mice}

After a moderate controlled cortical impact, every mouse injured demonstrated conspicuous trauma to the cortex immediately be-

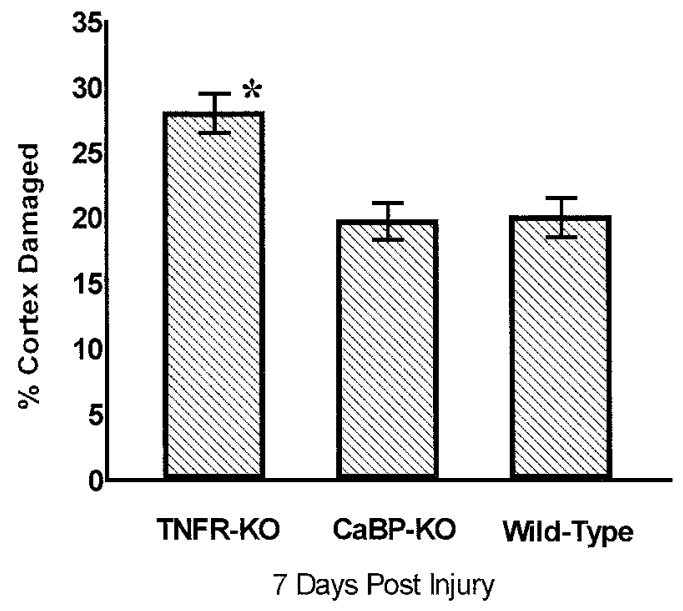

Figure 2. Traumatic brain injury is exacerbated in TNFR-KO mice but not in CaBP-KO mice. All mice received a unilateral $1 \mathrm{~mm}$ controlled cortical contusion and were killed $7 \mathrm{~d}$ after injury, and serial coronal sections were stained with cresyl violet. The mean percent cortical damage was calculated for each genotype using the Cavalieri principle (see Materials and Methods). Vertical bars represent group mean \pm SEM. The asterisk indicates a significant difference compared with wild type and CaBP-KO $(p<0.01)$.

low the impact site (Fig. 1). Seven days after injury, the cortical lesion volume was determined using the Cavalieri method (Michel and Cruz-Orive, 1988). An ANOVA revealed a significant group-dependent difference $\left[F_{(2,29)}=10.21 ; p<0.0004\right]$ in the percentage of the cortex damaged after TBI (Fig. 2). Post hoc comparisons indicated a significant increase $(p<0.01)$ in the mean percentage of cortex that was damaged in the TNFR-KO mice $(28.2 \%)$ compared with control (wild-type) mice $(20.2 \%)$ or CaBP-KO mice (19.7\%). No significant difference was measured between $\mathrm{CaBP}-\mathrm{KO}$ mice and control mice.

\section{Increased BBB disruption in TNFR-KO mice}

With the optical density of endogenous IgG immunoreactivity serving as a marker of BBB disruption after TBI, an ANOVA revealed a significant group-dependent difference $\left[F_{(2,29)}=10.82\right.$; $p<0.0003$ ] at $7 \mathrm{~d}$ after injury (Fig. 3). Post hoc comparisons revealed that the mean optical density of $\mathrm{IgG}$ immunoreactivity in the injured hemisphere of TNFR-KO mice (342.6) was signif- 


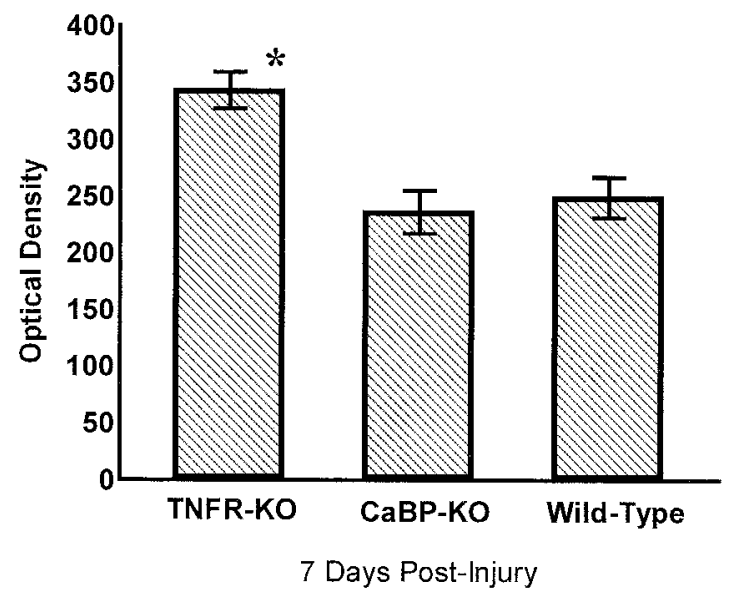

Figure 3. Optical density measurements of $\mathrm{IgG}$ after cortical contusions. Serial sections from each animal were stained with anti-mouse $\mathrm{IgG}$, and image analyses revealed a significant increase in the mean optical densities of IgG in the TNFR-KO versus wild-type mice. No difference was found between CaBP-KO and control animals. The increase in optical density indicates a more extensive breach of the blood-brain barrier in TNFR-KO animals, perhaps indicative of endothelial cell dysfunction. Vertical bars represent group mean \pm SEM. The asterisk indicates a significant difference compared with wild type and CaBP-KO $(p<0.01)$.

icantly increased $(p<0.01)$ compared with that of either CaBP-KO mice (236.3) or wild-type mice (249.4), with no significant difference measured between wild-type and CaBP-KO mice. Additionally, an ANOVA revealed a significant groupdependent difference $\left[F_{(2,29)}=40.64 ; p<0.0001\right]$ in the extent of IgG immunoreactivity (volume) at $7 \mathrm{~d}$ after injury. Post hoc analyses revealed that the extent of the $\mathrm{BBB}$ breach was also significantly increased $(p<0.01)$ in TNFR-KO $\left(3.8 \mathrm{~mm}^{3}\right)$ mice compared with wild-type $\left(2.9 \mathrm{~mm}^{3}\right)$ and CaBP-KO $\left(3.0 \mathrm{~mm}^{3}\right)$ mice (data not shown). No significant difference in the extent of the BBB breach was measured between wild-type and CaBP-KO mice. Additionally, the BBB appeared more permeable to exogenous blood-borne HRP at both 12 and $24 \mathrm{hr}$ after trauma in the TNFR-KO animals compared with control mice, although the extent of diffusion was more limited than that seen with $\mathrm{IgG}$ immunostaining (data not shown).

\section{Overexpression of MnSOD reduces cortical damage after TBI}

The cortical lesion volumes of transgenic mice that overexpress human MnSOD (MnSODtg) were compared with that of control littermates after the same controlled cortical contusion. Again, the Cavalieri method was used to quantify the extent of cortical damage $7 \mathrm{~d}$ after injury (Fig. 4). The mean percentages of the cortex damaged were analyzed using a two-tailed $t$ test and revealed a significant reduction $(p<0.05)$ in cortical damage measured in the MnSODtg mice compared with control mice.

\section{Reduced MnSOD expression in TNFR-KO mice}

Relative levels of MnSOD protein were measured using densitometric analysis of in situ MnSOD immunoreactivity. After a 1 $\mathrm{mm}$ controlled cortical contusion, immunoreactivity for MnSOD protein was measured in both the ipsilateral and contralateral hemispheres of TNFR-KO $(n=7)$ and wild-type $(n=7)$ mice at $9 \mathrm{hr}$ after injury (Fig. 5). The mean ipsilateral optical density was expressed as a percentage of the mean contralateral optical density for each mouse. A two-tailed $t$ test revealed a significant difference $(p<0.0001)$ between the groups, indicating that

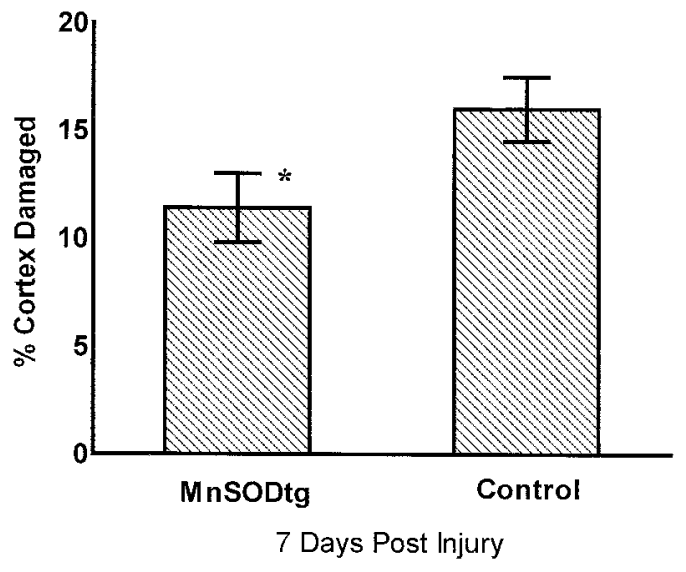

Figure 4. Animals generated to express human MnSOD (MnSODtg) demonstrated a significant reduction in the percentage of the cortex damaged compared with that of control littermates (control). All animals received a $1 \mathrm{~mm}$ controlled cortical impact and were killed $7 \mathrm{~d}$ after injury. Serial coronal sections were stained with cresyl violet, and the mean percentage of cortical damage was calculated using the Cavalieri principle (see Materials and Methods). Vertical bars represent group mean \pm SEM. The asterisk indicates a significant difference compared with control littermates $(p<0.05)$.

wild-type mice increase MnSOD expression in the ipsilateral cortex, whereas TNFR-KO mice show no changes in MnSOD expression after TBI (Fig. 6).

\section{Alteration of NF- $\kappa \mathrm{B}$ activation after TBI}

Nuclear NF- $\kappa \mathrm{B}$ activation in the injured cortex and hippocampus was measured by densitometric analysis and expressed as a percentage of NF- $\kappa \mathrm{B}$ activation measured in the corresponding contralateral regions (Fig. 7). An ANOVA revealed a significant time-dependent change in the means for the ipsilateral cortex $\left[F_{(5,12)}=39.69 ; p<0.0001\right]$ but not for the ipsilateral hippocampus. Post hoc analyses using two-tailed $t$ tests with the Bonferroni correction factor established significant differences between wildtype and TNFR-KO mice at the time points measured (Fig. 8). We found that activated $\mathrm{NF}-\kappa \mathrm{B}$ was approximately twofold greater in both the injured cortex and hippocampus of wild-type mice at 3, 12, and $24 \mathrm{hr}$ after injury. In contrast, the TNFR-KO mice demonstrated no changes in activated NF- $\kappa \mathrm{B}$ levels in the injured cortex at 3 or $12 \mathrm{hr}$ after injury, whereas a twofold increase was measured at $24 \mathrm{hr}$ after injury in the same region. The levels of activated NF- $\kappa \mathrm{B}$ measured in the injured hippocampus showed a twofold increase at 3, 12, and $24 \mathrm{hr}$ after injury, similar to controls.

\section{DISCUSSION}

Collectively, our results show that after TBI both the lesion volume and breakdown of the BBB were significantly greater in TNFR-KO mice than in wild-type or CaBP-KO mice. Additionally, NF- $\kappa$ B activation was delayed after TBI in TNFR-KO mice, suggesting that TNFR-mediated $\mathrm{NF}-\kappa \mathrm{B}$ activation may initiate neuroprotective pathways early in the injury process, perhaps via the induction of MnSOD. This concept is supported by the significant sparing of cortical tissue observed in MnSODtg mice compared with control littermates, as well as the reduced MnSOD expression in TNFR-KO mice after TBI. Conversely, we found that calbindin, also a gene target of NF- $\kappa \mathrm{B}$, does not appear to be involved in the TNFR-mediated tissue preservation.

Although studies in vitro have indicated that $\mathrm{TNF} \alpha$ secreted by 


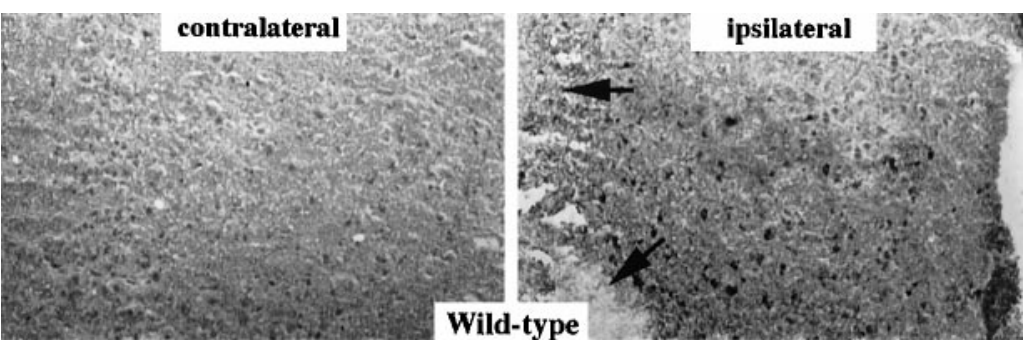

Figure 5. Low-power photomicrographs illustrating that MnSOD immunostaining is intensified in the penumbra of the ipsilateral hemisphere of wild-type animals but not of TNFR-KO animals after TBI. All animals received a $1 \mathrm{~mm}$ controlled cortical impact and were killed $9 \mathrm{hr}$ after injury. Fresh-frozen coronal brain sections were thaw-mounted on slides, incubated in the presence of sheep polyclonal antibody to $\mathrm{MnSOD}$, and then stained with biotinylated anti-mouse $\mathrm{IgG}$; the ABC method was used with diaminobenzidine as the chromogen. Arrows indicate the injured cortex.

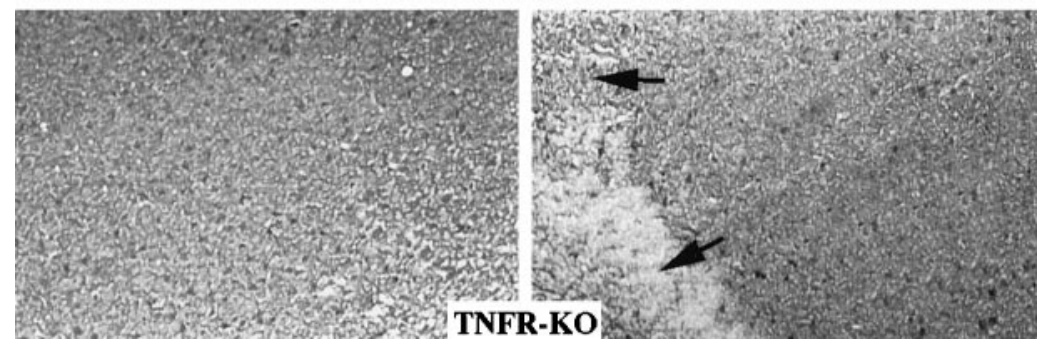

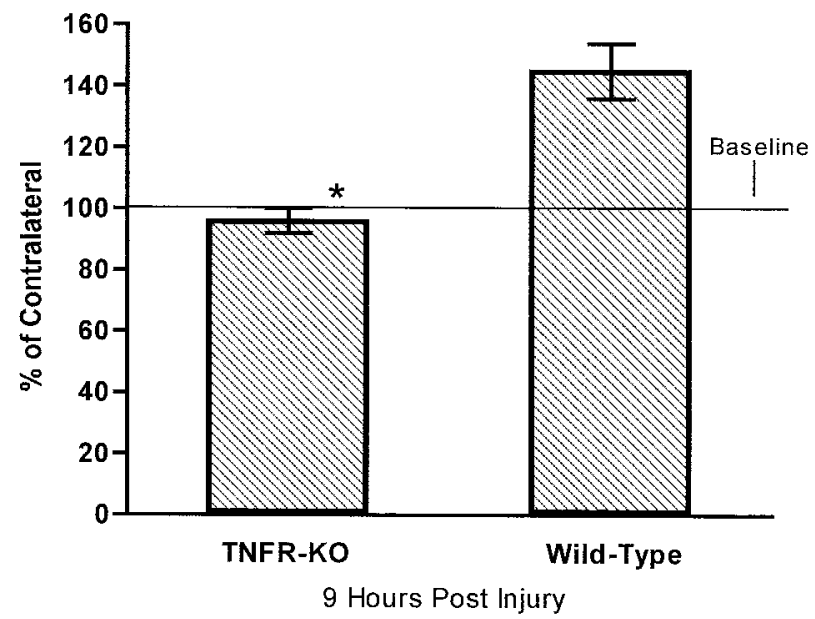

Figure 6. A controlled cortical impact $(1 \mathrm{~mm})$ results in increased MnSOD immunofluorescence in wild-type $(n=7)$ but not TNF receptordeficient (TNFR-KO; $n=7$ ) mice. MnSOD immunofluorescence in the injured cortex of TNFR-KO or wild-type mice is expressed as a percentage of that in the corresponding contralateral cortex. All mice were killed $9 \mathrm{hr}$ after injury (see Materials and Methods). Vertical bars represent group mean $\pm \mathrm{SD}$. The asterisk indicates a significant difference compared with wild-type mice $(p<0.0001)$.

activated microglia/macrophages and astrocytes has cytotoxic actions on non-neuronal cells (Selmaj and Raine, 1988; Sawada et al., 1989; Tracey and Lowry, 1990; Zajicek et al., 1992; Tracey and Cerami, 1994; van der Poll and Lowry, 1995), other data in vivo suggest that $\mathrm{TNF} \alpha$ has a neuroprotective role after CNS insults (Cheng et al., 1994; Barger et al., 1995; Mattson et al., 1995, 1997a,b; Liu et al., 1998). For example, recent in vivo evidence demonstrates that the administration of $\mathrm{TNF} \alpha$ is neuroprotective after an ischemic insult and reduces infarct volume (Nawashiro et al., 1997). Additionally, a recent study using TNFR-KO mice demonstrates that TNFR-KO mice sustain increased neuronal damage after excitotoxin injections, as well as greater infarct areas after middle cerebral artery occlusion, but demonstrate a TNF $\alpha$ response identical to that of wild-type mice (Bruce et al., 1996). Although the precise mechanisms for neuroprotection afforded by endogenous $\mathrm{TNF} \alpha$ remain uncertain, increased levels of oxidative stress were suggested to contribute to the exacerbated damage seen in TNFR-KO mice.

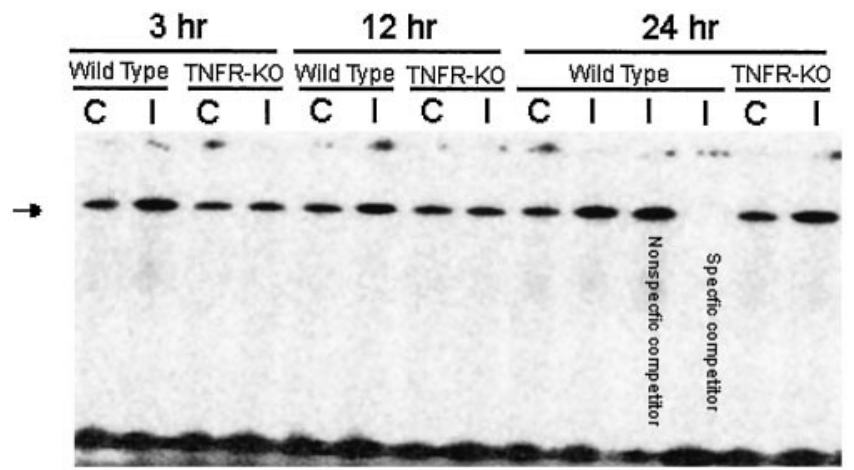

Figure 7. Electrophoretic mobility gel-shift assay for NF- $\kappa \mathrm{B}$ activation reveals an increase in NF- $\kappa \mathrm{B}$ activation in the ipsilateral injured cortex $(I)$ of wild type compared with that in the contralateral cortex $(C)$ at all times examined after injury ( 3,12 , and $24 \mathrm{hr})$. In contrast, TNF $\alpha$ receptor-deficient (TNFR-KO) mice demonstrated an increase in NF- $\kappa$ B activation only at $24 \mathrm{hr}$ after injury. All animals received a $1 \mathrm{~mm}$ controlled cortical impact and were killed at 3,12 , or $24 \mathrm{hr}$ after injury. Nuclear extracts were then prepared and used for gel-shift assays using a commercially available assay kit (please see Materials and Methods). A single prominent band interacts (shifts) with our radiolabeled $\kappa \mathrm{B}$ DNA (arrow). Control reactions included the substitution of nonspecific competitor DNA (no change in band) in place of the radiolabeled $\kappa \mathrm{B}$ DNA and the addition of unlabeled competitor DNA (blocked interaction) to the reaction mixture.

Evidence is mounting that the pivotal step in cell death is mitochondrial oxidative stress and/or dysfunction, with recent findings that apoptotic stimuli cause increased accumulation of mitochondrial reactive oxygen species (Richter et al., 1995; Shearman et al., 1995; Zamzami et al., 1995). These studies indicate that a reduction in antioxidant production would act to increase the susceptibility of neurons to insult. The capability of TNF $\alpha$ and $\mathrm{NF}-\kappa \mathrm{B}$ in protecting cultured neurons against death induced by excitotoxic, metabolic, and oxidative insults is well documented (Cheng et al., 1994; Barger et al., 1995; Barger and Mattson, 1996; Goodman and Mattson, 1996; Mattson et al., 1997b). Moreover, genetic alterations in NF- $\kappa$ B subunits and signaling pathways have reinforced the evidence that activation of $\mathrm{NF}-\kappa \mathrm{B}$ prevents apoptosis in a variety of non-neuronal cell types (Beg et al., 1995; Beg and Baltimore, 1996; Van Antwerp et al., 1996; Wu et al., 1996; Bellas et al., 1997; Lezoualc'h et al., 1998). $\mathrm{NF}-\kappa \mathrm{B}$ was originally studied in the immune system where it 

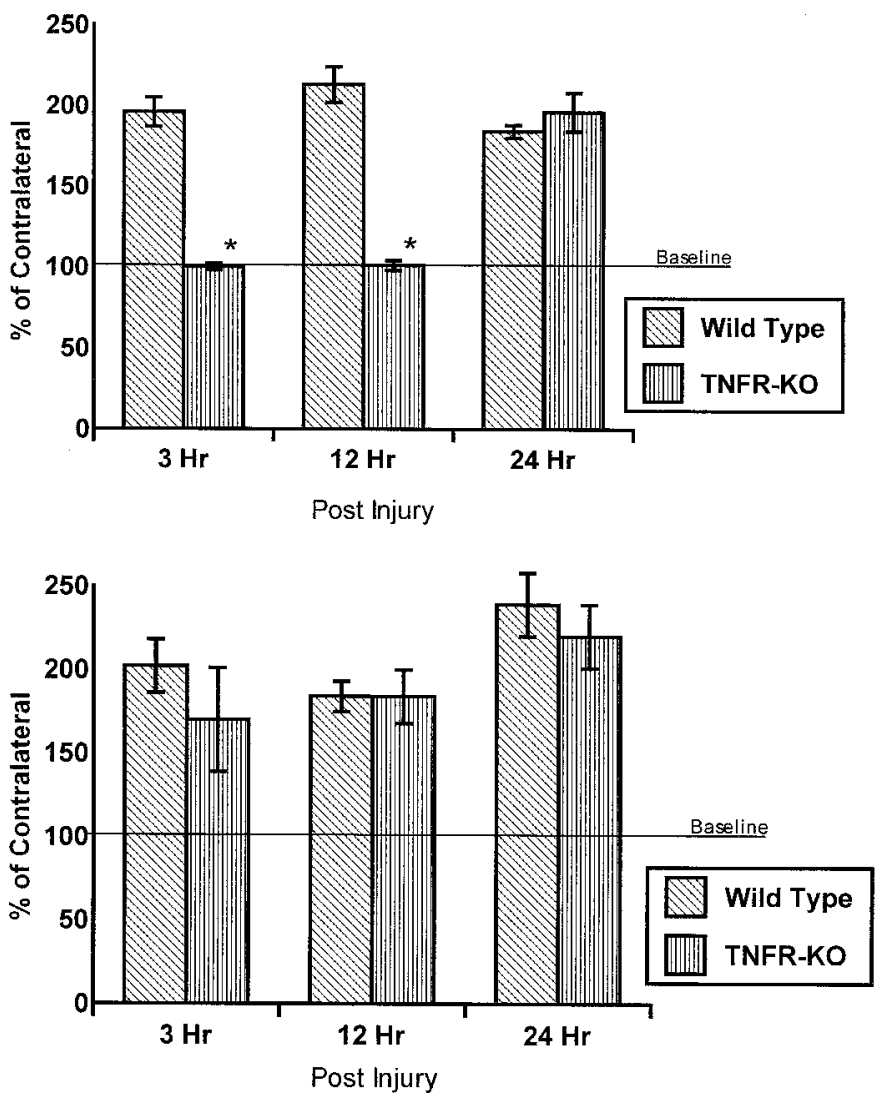

Figure 8. Nuclear NF- $\kappa \mathrm{B}$ activation in the ipsilateral injured cortex (top) and the hippocampus (bottom) of TNF $\alpha$ receptor-deficient (TNFR-KO) versus wild-type mice, expressed as a percentage of contralateral NF- $\kappa \mathrm{B}$ activation in the same regions. All animals received a $1 \mathrm{~mm}$ unilateral controlled cortical contusion and were killed at 3,12, or $24 \mathrm{hr}$ after injury. Nuclear extracts were then prepared, and NF- $\kappa$ B activation was determined using a gel-shift assay (see Materials and Methods). Vertical bars represent group mean \pm SEM. Asterisks indicate a significant difference compared with wild-type mice $(p<0.01)$.

regulates cell survival (for review, see Baeuerle and Henkel, 1994), but it is widely expressed in the CNS in both an inducible and constitutively active form (Kaltschmidt et al., 1993a,b, 1994; O'Neill and Kaltschmidt, 1997). The exact functions of NF- $\kappa$ B in the CNS are primarily unknown, but an emerging body of evidence implicates a consequential role for $\mathrm{NF}-\kappa \mathrm{B}$ based on its activation in various injury paradigms (Devary et al., 1993; Meyer et al., 1994; Prasad et al., 1994; McIntosh and Raghupathi, 1995; Yang et al., 1995; O'Neill and Kaltschmidt, 1997; Mattson, 1997). One of the possible target genes of NF- $\kappa \mathrm{B}$ activation via $\mathrm{TNF} \alpha$ is that of the antioxidant MnSOD, which is upregulated in response to TNF $\alpha$ in a variety of paradigms (Das et al., 1995; Wong, 1995; Wong et al., 1996; Hachiya et al., 1997; Isoherranen et al., 1997; Jones et al., 1997).

MnSOD is a superoxide dismutase associated specifically with mitochondria in which it captures and reduces free radicals, preventing oxidative damage to mitochondria and surrounding organelles. Free radical damage has long been held as a key element in promoting neuronal cell death in CNS trauma (Braughler and Hall, 1989, 1992; Hall and Braughler, 1989, 1993), whereas overexpression of MnSOD has been shown to prevent neuronal cell death by suppression of peroxynitrite production and lipid peroxidation (Keller et al., 1998). Additionally, overex- pression of CuZnSOD after brain injury has proven to be effective (for review, see Chan et al., 1995). Therefore, alterations in the induction of MnSOD because of delayed NF- $\kappa \mathrm{B}$ activation appear especially detrimental after TBI, particularly in light of recent studies from our lab and others that found alterations in ionic homeostasis and increased oxidative stress after TBI and spinal cord injury (Azbill et al., 1997; Sullivan et al., 1998).

The increased permeability of $\mathrm{IgG}$ and other serum proteins across the BBB after TBI is well documented (Povlishock and Kontos, 1992; Dietrich et al., 1994; Baldwin et al., 1996; Baskaya et al., 1997), so the augmented BBB breakdown in TNFR-KO mice may be directly linked to the increased tissue destruction. Accordingly, the significant increase in the lesion volume might indicate a corresponding increase in glutamate release from damaged neurons and glia, because recent studies have shown that antagonists to glutamate NMDA receptors reduce BBB disruption after various paradigms and insults (Stevens and Yaksh, 1990; Koenig et al., 1992; Nag, 1992; Dietrich et al., 1994; Belayev et al., 1995; Du et al., 1996; Miller et al., 1996; Baskaya et al., 1997). However, although this may afford a partial explanation for our results, the lack of TNFR that is normally expressed on CNS neurons, neuroglia, and endothelial cells prevents definitive conclusions regarding the underlying mechanisms for increased serum protein extravasation. Additionally, previous reports using strategies to block $\mathrm{TNF} \alpha$ production after a closed head injury using pentoxifylline and TNF-binding protein (Shohami et al., 1996) indicated a reduced peak edema formation at $24 \mathrm{hr}$ and facilitated recovery of motor function up to $4 \mathrm{~d}$ after injury as well as a reduced $\mathrm{BBB}$ breach. Interestingly, a recent study assessing behavioral outcome $24 \mathrm{hr}$ after closed head injury reported improvements using the NMDA receptor antagonist HU-211, which the authors described as a novel inhibitor of TNF $\alpha$ (Shohami et al., 1997). Although this would appear to contradict our findings, it should be emphasized that this short-time course study did not examine lesion volume or the extent of BBB breach, which the authors had determined to be reduced in previous studies using HU-211 (Nadler et al., 1995), nor did they consider the putative protective effects of HU-211 on the BBB integrity as a possible explanation for the acute behavioral improvements.

In conclusion, the results of these experiments show that after TBI the TNFR-KO mice demonstrate significantly larger lesion volumes and a reduction in MnSOD expression compared with that of wild types that express TNFR. In addition, overexpression of MnSOD, a target gene product of $\mathrm{TNF} \alpha$, significantly reduced cortical damage after TBI. A rapid increase in NF- $\kappa$ B activation is reported to occur after TBI (Yang et al., 1995) and spinal cord injury (Bethea et al., 1998) in rats, but to our knowledge the present study is the first to report a delay in NF- $\kappa \mathrm{B}$ activation and MnSOD expression after TBI in mice lacking TNFR. These findings confirm and histologically extend our previous report that TNFR-KO mice undergo more extensive neurodegeneration and ischemic cell death compared with that of wild types after various CNS insults (Bruce et al., 1996). Therefore, elevated levels of endogenous TNF $\alpha$ appear to play a critical role in the sparing of damaged tissue after TBI, quite possibly affording direct neuroprotection to affected neurons that express TNFR in normal mice. Moreover, the results of our study, together with reports of the anti-inflammatory actions of $\mathrm{TNF} \alpha$ (Liu et al., 1998), infer that therapeutic strategies aimed at suppressing and/or blocking the production of TNF $\alpha$ after TBI should be reevaluated. 


\section{REFERENCES}

Airaksinen MS, Eilers J, Garaschuk O, Thoenen H, Konnerth A, Meyer M (1997) Ataxia and altered dendritic calcium signaling in mice carrying a targeted null mutation of the calbindin D28k gene. Proc Natl Acad Sci USA 94:1488-1493.

Andersson PB, Perry VH, Gordon S (1991) The kinetics and morphological characteristics of the macrophage-microglial response to kainic acid-induced neuronal degeneration. Neuroscience 42:201-214.

Andrews NC, Faller DV (1991) A rapid micropreparation technique for extraction of DNA-binding proteins from limiting numbers of mammalian cells. Nucleic Acids Res 19:2499.

Azbill RD, Mu X, Bruce-Keller AJ, Mattson MP, Springer JE (1997) Impaired mitochondrial function, oxidative stress and altered antioxidant enzyme activities following traumatic spinal cord injury. Brain Res 765:283-290.

Baeuerle PA, Henkel T (1994) Function and activation of NF-kappa B in the immune system. Annu Rev Immunol 12:141-179.

Baldwin SA, Fugaccia I, Brown DR, Brown LV, Scheff SW (1996) Blood-brain barrier breach following cortical contusion in the rat. J Neurosurg 85:476-481.

Baldwin SA, Gibson T, Callihan CT, Sullivan PG, Palmer E, Scheff SW (1997) Neuronal cell loss in the CA3 subfield of the hippocampus following cortical contusion utilizing the optical dissector method for cell counting. J Neurotrauma 14:385-398.

Barger SW, Mattson MP (1996) Induction of neuroprotective kappa B-dependent transcription by secreted forms of the Alzheimer's betaamyloid precursor. Brain Res Mol Brain Res 40:116-126.

Barger SW, Horster D, Furukawa K, Goodman Y, Krieglstein J, Mattson MP (1995) Tumor necrosis factors alpha and beta protect neurons against amyloid beta-peptide toxicity: evidence for involvement of a kappa B-binding factor and attenuation of peroxide and $\mathrm{Ca} 2+$ accumulation. Proc Natl Acad Sci USA 92:9328-9332.

Baskaya MK, Rao AM, Dogan A, Donaldson D, Dempsey RJ (1997a) The biphasic opening of the blood-brain barrier in the cortex and hippocampus after traumatic brain injury in rats. Neurosci Lett 226:33-36.

Baskaya MK, Rao AM, Donaldson D, Prasad MR, Dempsey RJ (1997b) Protective effects of ifenprodil on ischemic injury size, blood-brain barrier breakdown, and edema formation in focal cerebral ischemia. Neurosurgery 40:364-370; discussion 370-371.

Beg AA, Baltimore D (1996) An essential role for NF-kappaB in preventing TNF-alpha-induced cell death [see comments]. Science 274:782-784.

Beg AA, Sha WC, Bronson RT, Ghosh S, Baltimore D (1995) Embryonic lethality and liver degeneration in mice lacking the RelA component of NF-kappa B. Nature 376:167-170.

Belayev L, Busto R, Watson BD, Ginsberg MD (1995) Post-ischemic administration of HU-211, a novel non-competitive NMDA antagonist, protects against blood-brain barrier disruption in photochemical cortical infarction in rats: a quantitative study. Brain Res 702:266-270.

Bellas RE, FitzGerald MJ, Fausto N, Sonenshein GE (1997) Inhibition of NF-kappa B activity induces apoptosis in murine hepatocytes. Am J Pathol 151:891-896.

Bethea JR, Castro M, Keane RW, Lee TT, Dietrich WD, Yezierski RP (1998) Traumatic spinal cord injury induces nuclear factor-kappaB activation. J Neurosci 18:3251-3260.

Beutler B, Van Huffel C (1994a) An evolutionary and functional approach to the TNF receptor/ligand family. Ann NY Acad Sci 730:118-133.

Beutler B, Van Huffel C (1994b) Unraveling function in the TNF ligand and receptor families [comment]. Science 264:667-668.

Braughler JM, Hall ED (1989) Central nervous system trauma and stroke. I. Biochemical considerations for oxygen radical formation and lipid peroxidation. Free Radic Biol Med 6:289-301.

Braughler JM, Hall ED (1992) Involvement of lipid peroxidation in CNS injury. J Neurotrauma 9[Suppl 1]:S1-S7.

Bruce AJ, Boling W, Kindy MS, Peschon J, Kraemer PJ, Carpenter MK, Holtsberg FW, Mattson MP (1996) Altered neuronal and microglial responses to excitotoxic and ischemic brain injury in mice lacking TNF receptors. Nat Med 2:788-794.

Chan PH, Epstein CJ, Li Y, Huang TT, Carlson E, Kinouchi H, Yang G, Kamii H, Mikawa S, Kondo T, et al. (1995) Transgenic mice and knockout mutants in the study of oxidative stress in brain injury. J Neurotrauma 12:815-824.

Cheng B, Christakos S, Mattson MP (1994) Tumor necrosis factors protect neurons against metabolic-excitotoxic insults and promote maintenance of calcium homeostasis. Neuron 12:139-153.

Coffey PJ, Perry VH, Rawlins JN (1990) An investigation into the early stages of the inflammatory response following ibotenic acid-induced neuronal degeneration. Neuroscience 35:121-132.

Das KC, Lewis-Molock Y, White CW (1995) Thiol modulation of TNF alpha and IL-1 induced MnSOD gene expression and activation of NF-kappa B. Mol Cell Biochem 148:45-57.

Devary Y, Rosette C, DiDonato JA, Karin M (1993) NF-kappa B activation by ultraviolet light not dependent on a nuclear signal. Science 261:1442-1445.

Dietrich WD, Alonso O, Halley M (1994) Early microvascular and neuronal consequences of traumatic brain injury: a light and electron microscopic study in rats. J Neurotrauma 11:289-301.

Du C, Hu R, Hsu CY, Choi DW (1996) Dextrorphan reduces infarct volume, vascular injury, and brain edema after ischemic brain injury. J Neurotrauma 13:215-222.

Fan L, Young PR, Barone FC, Feuerstein GZ, Smith DH, McIntosh TK (1996) Experimental brain injury induces differential expression of tumor necrosis factor-alpha mRNA in the CNS. Brain Res Mol Brain Res 36:287-291.

Feuerstein GZ, Wang X, Barone FC (1997) Inflammatory gene expression in cerebral ischemia and trauma. Potential new therapeutic targets. Ann NY Acad Sci 825:179-193.

Goodman JC, Robertson CS, Grossman RG, Narayan RK (1990) Elevation of tumor necrosis factor in head injury. J Neuroimmunol 30:213-217.

Goodman Y, Mattson MP (1996) Ceramide protects hippocampal neurons against excitotoxic and oxidative insults, and amyloid beta-peptide toxicity. J Neurochem 66:869-872.

Hachiya M, Shimizu S, Osawa Y, Akashi M (1997) Endogenous production of tumour necrosis factor is required for manganese superoxide dismutase expression by irradiation in the human monocytic cell line THP-1. Biochem J 328:615-623.

Hall ED, Braughler JM (1989) Central nervous system trauma and stroke. II. Physiological and pharmacological evidence for involvement of oxygen radicals and lipid peroxidation. Free Radic Biol Med 6:303-313.

Hall ED, Braughler JM (1993) Free radicals in CNS injury. Res Publ Assoc Res Nerv Ment Dis 71:81-105.

Isoherranen K, Peltola V, Laurikainen L, Punnonen J, Laihia J, Ahotupa M, Punnonen K (1997) Regulation of copper/zinc and manganese superoxide dismutase by UVB irradiation, oxidative stress and cytokines. J Photochem Photobiol B 40:288-293.

Jensen MB, Finsen B, Zimmer J (1997) Morphological and immunophenotypic microglial changes in the denervated fascia dentata of adult rats: correlation with blood-brain barrier damage and astroglial reactions. Exp Neurol 143:103-116.

Jones PL, Ping D, Boss JM (1997) Tumor necrosis factor alpha and interleukin-1beta regulate the murine manganese superoxide dismutase gene through a complex intronic enhancer involving C/EBPbeta and NF-kappaB. Mol Cell Biol 17:6970-6981.

Kaltschmidt B, Baeuerle PA, Kaltschmidt C (1993a) Potential involvement of the transcription factor NF-kappa B in neurological disorders. Mol Aspects Med 14:171-190.

Kaltschmidt C, Kaltschmidt B, Baeuerle PA (1993b) Brain synapses contain inducible forms of the transcription factor NF-kappa B. Mech Dev 43:135-147.

Kaltschmidt C, Kaltschmidt B, Neumann H, Wekerle H, Baeuerle PA (1994) Constitutive NF-kappa B activity in neurons. Mol Cell Biol 14:3981-3992.

Keller JN, Kindy MS, Holtsberg FW, St Clair DK, Yen HC, Germeyer A, Steiner SM, Bruce-Keller AJ, Hutchins JB, Mattson MP (1998) Mitochondrial manganese superoxide dismutase prevents neural apoptosis and reduces ischemic brain injury: suppression of peroxynitrite production, lipid peroxidation, and mitochondrial dysfunction. J Neurosci 18:687-697.

Kinouchi K, Brown G, Pasternak G, Donner DB (1991) Identification and characterization of receptors for tumor necrosis factor-alpha in the brain. Biochem Biophys Res Commun 181:1532-1538.

Koenig H, Trout JJ, Goldstone AD, Lu CY (1992) Capillary NMDA 
receptors regulate blood-brain barrier function and breakdown. Brain Res 588:297-303.

Kolesnick R, Golde DW (1994) The sphingomyelin pathway in tumor necrosis factor and interleukin-1 signaling. Cell 77:325-328.

Lezoualc'h F, Sagara Y, Holsboer F, Behl C (1998) High constitutive NF-kappaB activity mediates resistance to oxidative stress in neuronal cells. J Neurosci 18:3224-3232.

Liu J, Marino MW, Wong G, Grail D, Dunn A, Bettadapura J, Slavin AJ, Old L, Bernard CC (1998) TNF is a potent anti-inflammatory cytokine in autoimmune-mediated demyelination. Nat Med 4:78-83.

Liu T, Clark RK, McDonnell PC, Young PR, White RF, Barone FC, Feuerstein GZ (1994) Tumor necrosis factor-alpha expression in ischemic neurons. Stroke 25:1481-1488.

Lowenstein DH, Gwinn RP, Seren MS, Simon RP, McIntosh TK (1994) Increased expression of mRNA encoding calbindin-D28K, the glucoseregulated proteins, or the $72 \mathrm{kDa}$ heat shock protein in three models of acute CNS injury. Mol Brain Res 22:299-308.

Mattson MP (1997) Neuroprotective signal transduction: relevance to stroke. Neurosci Biobehav Rev 21:193-206.

Mattson MP, Scheff SW (1994) Endogenous neuroprotection factors and traumatic brain injury: mechanisms of action and implications for therapy. J Neurotrauma 11:3-33.

Mattson MP, Rychlik B, Chu C, Christakos S (1991) Evidence for calcium-reducing and excitoprotective roles for the calcium-binding protein calbindin-D28k in cultured hippocampal neurons. Neuron 6:41-51.

Mattson MP, Cheng B, Baldwin SA, Smith-Swintosky VL, Keller J, Geddes JW, Scheff SW, Christakos S (1995) Brain injury and tumor necrosis factors induce calbindin D-28k in astrocytes: evidence for a cytoprotective response. J Neurosci Res 42:357-370.

Mattson MP, Barger SW, Furukawa K, Bruce AJ, Wyss-Coray T, Mark RJ, Mucke L (1997a) Cellular signaling roles of TGF beta, TNF alpha and beta APP in brain injury responses and Alzheimer's disease. Brain Res Brain Res Rev 23:47-61.

Mattson MP, Goodman Y, Luo H, Fu W, Furukawa K (1997b) Activation of NF-kappaB protects hippocampal neurons against oxidative stress-induced apoptosis: evidence for induction of manganese superoxide dismutase and suppression of peroxynitrite production and protein tyrosine nitration. J Neurosci Res 49:681-697.

McIntosh TK, Raghupathi R (1995) Cell stress genes and acute CNS injury. Neuropathol Appl Neurobiol 21:477-479.

Merrill JE (1991) Effects of interleukin-1 and tumor necrosis factoralpha on astrocytes, microglia, oligodendrocytes, and glial precursors in vitro. Dev Neurosci 13:130-137.

Mesulam MM (1978) Tetramethyl benzidine for horseradish peroxidase neurohistochemistry: a non-carcinogenic blue reaction product with superior sensitivity for visualizing neural afferents and efferents. J Histochem Cytochem 26:106-117.

Meyer M, Pahl HL, Baeuerle PA (1994) Regulation of the transcription factors NF-kappa B and AP-1 by redox changes. Chem Biol Interact 91:91-100.

Michel RP, Cruz-Orive LM (1988) Application of the Cavalieri principle and vertical sections method to lung: estimation of volume and pleural surface area. J Microsc 150:117-136.

Miller RD, Monsul NT, Vender JR, Lehmann JC (1996) NMDA- and endothelin-1-induced increases in blood-brain barrier permeability quantitated with Lucifer yellow. J Neurol Sci 136:37-40.

Morganti-Kossmann MC, Kossmann T, Wahl SM (1992) Cytokines and neuropathology. Trends Pharmacol Sci 13:286-291.

Nadler V, Biegon A, Beit-Yannai E, Adamchik J, Shohami E (1995) $45 \mathrm{Ca}$ accumulation in rat brain after closed head injury; attenuation by the novel neuroprotective agent HU-211. Brain Res 685:1-11.

Nag S (1992) Vascular changes in the spinal cord in $N$-methyl-Daspartate-induced excitotoxicity: morphological and permeability studies. Acta Neuropathol (Berl) 84:471-477.

Nawashiro H, Tasaki K, Ruetzler CA, Hallenbeck JM (1997) TNFalpha pretreatment induces protective effects against focal cerebral ischemia in mice. J Cereb Blood Flow Metab 17:483-490.

O’Neill LA, Kaltschmidt C (1997) NF-kappa B: a crucial transcription factor for glial and neuronal cell function. Trends Neurosci 20:252-258.

Paxinos G, Watson C (1982) The rat brain in stereotaxic coordinates. Sydney: Academic.

Pfeffer K, Matsuyama T, Kundig TM, Wakeham A, Kishihara K, Shahinian A, Wiegmann K, Ohashi PS, Kronke M, Mak TW (1993) Mice deficient for the $55 \mathrm{kd}$ tumor necrosis factor receptor are resistant to endotoxic shock, yet succumb to L. monocytogenes infection. Cell 73:457-467.

Povlishock JT, Kontos HA (1992) The role of oxygen radicals in the pathobiology of traumatic brain injury. Hum Cell 5:345-353.

Prasad AV, Pilcher WH, Joseph SA (1994) Nuclear factor-kappa B in rat brain: enhanced DNA-binding activity following convulsant-induced seizures. Neurosci Lett 170:145-148.

Richter C, Gogvadze V, Laffranchi R, Schlapbach R, Schweizer M, Suter M, Walter P, Yaffee M (1995) Oxidants in mitochondria: from physiology to diseases. Biochim Biophys Acta 1271:67-74.

Sawada M, Kondo N, Suzumura A, Marunouchi T (1989) Production of tumor necrosis factor-alpha by microglia and astrocytes in culture. Brain Res 491:394-397.

Scharfman HA, Schwartzkroin PA (1989) Protection of dentate hilar cells from prolonged stimulation by intracellular calcium chelation. Science 246:257-260.

Scheff SW, Baldwin SA, Brown RW, Kraemer PJ (1997) Morris water maze deficits in rats following traumatic brain injury: lateral controlled cortical impact. J Neurotrauma 14:615-627.

Selmaj KW, Raine CS (1988) Tumor necrosis factor mediates myelin and oligodendrocyte damage in vitro. Ann Neurol 23:339-346.

Shearman MS, Hawtin SR, Tailor VJ (1995) The intracellular component of cellular 3-(4,5-dimethylthiazol-2-yl)-2,5-diphenyltetrazolium bromide (MTT) reduction is specifically inhibited by beta-amyloid peptides. J Neurochem 65:218-227.

Shohami E, Bass R, Wallach D, Yamin A, Gallily R (1996) Inhibition of tumor necrosis factor alpha (TNFalpha) activity in rat brain is associated with cerebroprotection after closed head injury. J Cereb Blood Flow Metab 16:378-384.

Shohami E, Gallily R, Mechoulam R, Bass R, Ben-Hur T (1997) Cytokine production in the brain following closed head injury: dexanabinol (HU-211) is a novel TNF-alpha inhibitor and an effective neuroprotectant. J Neuroimmunol 72:169-177.

Siesjo BK, Katsura K, Zhao Q, Folbergrova J, Pahlmark K, Siesjo P, Smith ML (1995) Mechanisms of secondary brain damage in global and focal ischemia: a speculative synthesis. J Neurotrauma 12:943-956.

Soares HD, Hicks RR, Smith D, McIntosh TK (1995) Inflammatory leukocytic recruitment and diff use neuronal degeneration are separate pathological processes resulting from traumatic brain injury. J Neurosci 15:8223-8233.

Stevens MK, Yaksh TL (1990) Systematic studies on the effects of the NMDA receptor antagonist MK-801 on cerebral blood flow and responsivity, EEG, and blood-brain barrier following complete reversible cerebral ischemia. J Cereb Blood Flow Metab 10:77-88.

Sullivan PG, Keller JN, Mattson MP, Scheff SW (1998) Traumatic brain injury alters synaptic homeostasis: implications for impaired mitochondrial and transport function. J Neurotrauma 15:789-798.

Tartaglia LA, Weber RF, Figari IS, Reynolds C, Palladino Jr MA, Goeddel DV (1991) The two different receptors for tumor necrosis factor mediate distinct cellular responses. Proc Natl Acad Sci USA 88:9292-9296.

Taupin V, Toulmond S, Serrano A, Benavides J, Zavala F (1993) Increase in IL-6, IL-1 and TNF levels in rat brain following traumatic lesion. Influence of pre- and post-traumatic treatment with Ro5 4864, a peripheral-type ( $\mathrm{p}$ site) benzodiazepine ligand. J Neuroimmunol 42:177-185.

Tracey KJ, Cerami A (1994) Tumor necrosis factor: a pleiotropic cytokine and therapeutic target. Annu Rev Med 45:491-503.

Tracey KJ, Lowry SF (1990) The role of cytokine mediators in septic shock. Adv Surg 23:21-56.

Van Antwerp DJ, Martin SJ, Kafri T, Green DR, Verma IM (1996) Suppression of TNF-alpha-induced apoptosis by NF-kappaB [see comments]. Science 274:787-789.

van der Poll T, Lowry SF (1995) Tumor necrosis factor in sepsis: mediator of multiple organ failure or essential part of host defense? [editorial]. Shock 3:1-12.

Wolvers DA, Marquette C, Berkenbosch F, Haour F (1993) Tumor necrosis factor-alpha: specific binding sites in rodent brain and pituitary gland. Eur Cytokine Netw 4:377-381.

Wong GH (1995) Protective roles of cytokines against radiation: induction of mitochondrial MnSOD. Biochim Biophys Acta 1271:205-209.

Wong GH, Kaspar RL, Vehar G (1996) Tumor necrosis factor and lymphotoxin: protection against oxidative stress through induction of MnSOD. EXS 77:321-333.

Wu M, Lee H, Bellas RE, Schauer SL, Arsura M, Katz D, FitzGerald MJ, 
Rothstein TL, Sherr DH, Sonenshein GE (1996) Inhibition of NF$\mathrm{kappaB} / \mathrm{Rel}$ induces apoptosis of murine B cells. EMBO J 15:46824690 .

Yang K, Mu XS, Hayes RL (1995) Increased cortical nuclear factorkappa B (NF-kappa B) DNA binding activity after traumatic brain injury in rats. Neurosci Lett 197:101-104.

Yen HC, Oberley TD, Vichitbandha S, Ho YS, St Clair DK (1996) The protective role of manganese superoxide dismutase against adriamycininduced acute cardiac toxicity in transgenic mice. J Clin Invest [Erratum (1997) 99:1141] 98:1253-1260.

Zajicek JP, Wing M, Scolding NJ, Compston DA (1992) Interactions between oligodendrocytes and microglia. A major role for complement and tumour necrosis factor in oligodendrocyte adherence and killing. Brain 115:1611-1631.

Zamzami N, Marchetti P, Castedo M, Decaudin D, Macho A, Hirsch T, Susin SA, Petit PX, Mignotte B, Kroemer G (1995) Sequential reduction of mitochondrial transmembrane potential and generation of reactive oxygen species in early programmed cell death. J Exp Med 182:367-377.

Zheng L, Fisher G, Miller RE, Peschon J, Lynch DH, Lenardo MJ (1995) Induction of apoptosis in mature $T$ cells by tumour necrosis factor. Nature 377:348-351. 